\title{
THE SigNIFICANCE OF THE SOUTH PACIFIC FOR COMPARATIVE STUDIES IN LABOUR LAW
}

\author{
BT Brooks"
}

In this paper Prof Brooks traces the introduction of labour law into the South Pacific island states and its development there. He considers the richness of the subject for interdisciplinary and comparative study, and indicates labour law as fertile ground for an investigation into the tensions in the Pacific states between tradition and modernisation.

There is very little published information about South Pacific labour law and industrial relations. A search of the Index to a leading text on law, government and politics in the region failed to disclose any mention of employment law or industrial law or labour law or wages or trade unions or collective bargaining, or employment contracts. ${ }^{1}$ A search in similar, earlier books reveals the same lack of attention to labour law in the region. This is a matter for regret. The experience of the independent island nations of the South Pacific as they move into a monetarised economy offers useful insights into the forces which shape the evolution of labour law and industrial relations. It also provides an opportunity to study the effect of exporting European laws and institutions and allows us to compare and contrast the process across a range of developing countries where the legacy of colonial administration varies and where the problem is to balance the importance of tradition and custom with the pressures of modern development. This means that one of the most interesting areas of comparative study is the impact of the jurisprudence of the nineteenth century colonial powers upon the customs and practices of the South Pacific. An example is the notion of an employer. This is a concept quite alien to the traditional, subsistence economy of the villages of the South Pacific, as is the concept of being paid money as a reward for work. A study of the introduction of these concepts should attract not only

* Professor and Dean of Law at Victoria Univeristy of Wellington.

1 Yash Ghai (ed) Law Politics and Government in the Pacific Island States (University of the South Pacific, 1988). 
lawyers but also sociologists and anthropologists and illustrates the point that modern comparative scholarship is best conducted in teams. The arrival of capitalism in lessdeveloped nations, and its growth within those countries, is a complex phenomenon which demands research from scholars across a range of disciplines to provide an empirical framework which will allow insights into what shapes labour law in less-developed countries. These issues confront independent nations in Asia, Latin America, the Caribbean and Africa as well as the South Pacific.

One traditional model for the post-independence governments of the South Pacific was that of the laissez-faire practices adjudged appropriate in Great Britain in the nineteenth century and exported in the period of colonisation. But the problem facing the newly independent island nations in the second half of the twentieth century was how to create a system which raised living standards and at the same time ensured industrial peace and the protection of indigenous workers. In the result the British voluntarist approach to settling industrial disputes through unregulated collective bargaining was not seen as appropriate for the South Pacific. Today the most common pattern of industrial regulation is one based on legislative intervention backed-up by an inspectorate, a labour tribunal and compulsory conciliation and arbitration. At the same time this policy has to accommodate cultural values concerning settling disputes. The tradition of village-based settlement of all disputes had, naturally, no backing in legislation. Nor did customary and unwritten law. An example is found in custom as a source of legal obligations. Custom is an obvious source of work obligations in the South Pacific and custom requires a certain amount of work being performed compulsorily for the village or the chief. At the same time, forced and indentured labour was a common feature of early western colonial rule in the South Pacific, especially in respect to plantation work. Immediately upon independence each of the island nations of the South Pacific legislated to prohibit any work arrangement which was not entered into voluntarily. An example is found in the Constitution of Western Samoa. While Article 8 prohibits forced or compulsory labour, those terms are not to be construed so as to include "any work or service which is required by Samoan custom or which forms part of normal civil obligation". This Article reveals the tension between removing the exploitation of colonial times while at the same time preserving custom and tradition.

Generalisations are dangerous but certain basic conditions are widely encountered in developing countries, such as the predominance of the agricultural sector, the small proportion of the labour force in the modern industrial sector, the concentration of urban wage earners in service occupations, the prevalence of under-employment co-existing with serious shortages of technical, white-collar and managerial skills, the role of the state as the major employer and the major regulator of the economy, the need to remove the exploitation of the colonial era, the tension between economic development and the protection of indigenous workers, the fragility of trade unions, the absence of workforce planning, the drift to the towns and away from the villages with associated unemployment and pressure 
on the social and physical infrastructure of the towns. Furthermore, the government in each of the island nations of the South Pacific is the largest employer and in most countries the conditions of employment of public servants are generally the most attractive. These conditions were established partly for the benefit of expatriate personnel of the colonial era and have to be revised to suit the needs of independence.

In the South Pacific different island nations are industrialising at different speeds. But common to all are two questions. The first is whether "development" means the sacrifice of traditional culture. The second is whether capitalist and non-capitalist economic activity can co-exist in less industrially developed countries. Many studies in the past explored the influence of industrialism on traditional culture and forms and two views emerged. ${ }^{2}$ One view saw the introduction of capitalism into the so-called "less developed'" countries as an affirmative good for workers. On the other hand some commentators saw the advent of capitalism in traditional societies as part of a process of impoverishment rather than one of enrichment for the countries concerned. The truth is somewhere in the middle and there is evidence that traditional, non-capitalist and capitalist economic activity can co-exist and inter-relate in less-developed countries. This co-existence is best demonstrated through labour and industrial law.

For the slowly industrialising island nations of the South Pacific there is a constant dilemma: how to achieve economic development while at the same time protecting the indigenous people from exploitation. This dilemma becomes especially acute when the Pacific governments turn their attention to legislating for trade unions. The trade union, which was once confined to "western" industrialised countries, has been exported. This process of exporting provides an opportunity to study the evolution of trade unionism in a range of developing countries. It also provides an opportunity to compare and contrast the process keeping in mind the obvious problem of deciding which countries to compare and contrast. There are reasons to believe that the experience of tropical Africa is at least as relevant to the development of trade unionism in the South Pacific as is the experience of the developed industrial nations. ${ }^{3}$

In 1964 the OECD organised a seminar on the role of trade unionism in independent developing countries. The developing countries at that time were seen as comprising much of Africa, parts of South America, most of the Caribbean, India and Turkey. There was no reference to Asia or the Pacific except for one paper on Malaya. But, looking back over 30 years, it is striking how much of what was written then is an accurate description of issues in industrial relations and industrial law in the South Pacific in the last years of the

2 Kerr, Dunlop, Harrison and Myers Industrialism and Industrial Man (London Heinemann 1962).

3 R M Martin "Tribesman into Trade Unionists: the African Experience and the Papua New Guinea Prospect" (1969) The Journal of Industrial Relations 125. 
twentieth century. An example is found in the paper prepared by Aahron Becker, at that time Secretary-General, Histadrut (the General Federation of Labour in Israel). That paper is published in the proceedings of the seminar and edited by Solomon Barkin, Head, OECD Social Affairs Division and the relevant passage is found at pages 21-22 in the following words: "If we scratch the surface of trade-unionism in most of the new and less-developed countries, we find a situation which hardly corresponds at all to usual notions of a proper or normal labour movement as understood in the industrially advanced countries. The outer shell may appear to be a fairly accurate copy of these older models, but underneath the special conditions attached to a nation in the course of development have given the unions quite another quality and tone and imposed on them an altogether different scale of priorities."

All societies face the problem of where to locate trade unions in the social, political, legal and economic framework and what status to accord them. The answer to these questions in the various island nations of the South Pacific is explicable in terms of the historical background. Two examples are the Cook Islands and the Republic of Vanuatu.

There is an historical link between the Cook Islands and New Zealand. New Zealand departed markedly from the voluntary, non-interventionist tradition of labour law as inherited from England and developed its own system of compulsory conciliation and arbitration of industrial disputes based on a philosophy of massive State intervention into the employer and employee relationship. ${ }^{4}$ As part of this system trade unions are accorded the status of trading corporations It is the historic example of compulsory conciliation and arbitration, first adopted in New Zealand in 1894, and followed in Australia in 1904, that explains the industrial laws of the Cook Islands. On the other hand the labour laws of the Republic of Vanuatu reflect that country's history as a colony jointly administered by England and France until the early 1980s. Thus the source of labour and industrial law for Vanuatu is a mixture of English common law and statute and the Continental Code and a study of the adaptation of this background to the needs of an industrialising Pacific Island nation offers much to interest the comparativist.

The most extreme illustration of the tensions involved in adapting European labour law and institutions under the pressures of a different environment is found in the recent history of the Republic of Fiji. ${ }^{5}$ The first action of the leaders of the 1987 coup was to close down the trade union headquarters and in 1990 the Fiji Times carried a report of an address in which the coup leader (and now the Prime Minister) Major-General Sitiveni Rabuka,

4 In the course of the past 15 years New Zealand has abolished the traditional system of compulsory arbitration. Under the present Employment Contracts Act 1991 all employment is regulated by voluntary contracts. It is unlikely that the Cook Islands will adopt this approach.

5 For a review of the coups see C McGregor "The Pacific in 1987" (1988) 1 The Pacific Review 196. 
"called for curbs on trade unions". The General was reported to have said in the same speech that "our individual freedom, aspirations and dreams will have to be curbed in the interests of the nation". This experience confirms the observation of Galeson, writing in 1964 , that "[T]rade unionism is not a very hardy flower, it is particularly susceptible to the winds of politics and to economic adversity. It is small wonder that nations which are unstable politically and struggling desperately to develop their economic resources do not exhibit powerful, well-functioning labour movements. The line of least resistance, the one followed in all too many cases, is to deprive the unions of independence of action, if indeed they are permitted to exist at all." 6

A leading scholar on industrial relations in less developed countries has made the point that while it is true that industrial relations mechanisms in many newly independent nations was determined by their particular colonial histories, and that even postindependence the model adopted was that of particular industrialised nations, the more recent tendency has been for governments to move away from industrial relations practices based on democratic, developed economics towards other systems ${ }^{7}$. The argument for this tendency is that less-developed countries cannot afford the luxury of independent trade unions and collective bargaining. Thus what is emerging is industrial relations structures which are less democratic, which deprive trade unions of autonomous action, and which subordinate both management and labour to increasing degrees of government control. As Hesse observes: "once on this slippery path, the temptation has been strong for governments to seek solutions to particular industrial problems by further strengthening their regulatory mechanisms". 8

There is much evidence in the experience of South Pacific nations to support this conclusion but it needs to be emphasised that trade unions are legally permitted to exist in most of the South Pacific and much of the legislation regulating trade unions is familiar to students of trade unions in the English tradition. At the same time it is important to understand that trade unions in the South Pacific do not enjoy unfettered freedom and there are numerous legal controls upon trade unions both at the point of registration and once registered. In Pacific countries government influence is unlikely to be thrown on the side of trade unions. Over thirty years ago an observer of industrial relations in developing countries remarked: "Wage determination is too closely geared to growth potentialities to be left to bilateral settlement. Labour market negotiations will be closely supervised and agreements scrutinised for their impact on the economy. Even in the United States, we are

W Galinson Labour in Developing Countries, (University of California Press, 1962) 2.

7 M Hesse "How the Foreign Devils Got It Wrong: Understanding Industrial Relations in Less-Developed Countries" (1986) 28 Journal of Industrial Relations 225. 
beginning to realise that bilateral bargaining on a sectional basis may endanger national objectives. The amount of slack in an underdeveloped country is much less, and tolerance accordingly quite narrow". 9 "These observations appear to be confirmed by the experience of the island nations of the South Pacific. At the same time research is required into the proposition that trade unions in the Pacific accept the government's role in determining wage levels in exchange for legislation which ensures that employers must recognise trade unions and for protection in the form of minimum wage legislation, workplace health and safety legislation and protection from exploitation. Research also needs to be done into the response of employers to the interventionist role of governments in the South Pacific, in particular in terms of controlling the outcome of wage bargaining.

The issues of freedom and state regulation, of the right to associate and to strike, are of universal interest and the South Pacific provides rich material for comparative studies. There are two main reasons for this. First, because it is the state which confers and protects the right to associate, often in the form of provisions in the Constitution. Second, because in developing economies the consequences of strikes, lockouts and industrial disputes generally are considerable and include complete cessation of production and the danger of social and political disturbance. For this reason it can be argued that not only is government intervention justified but that collective bargaining should not be allowed. The contrary case has been argued by Roberts and Greyfrie drawing on studies in Africa. ${ }^{10}$ The problem is that, in practice, the governments in developing economies in the South Pacific impose conditions for the enjoyment of the right to associate (and to strike) which are so stringent as to nullify these "rights" completely. In this, as in many areas, the South Pacific provides many examples of the difference between "law in books" and "law in practice" and pose the question whether freedom of association and the rights which accompany it can only be sustained under specific social and political conditions. It also raises the related question of whether a future response to social, economic and political crises in the South Pacific will take the form of industrial action and here, also, students of comparative labour and industrial law have a fertile field to plough. ${ }^{11}$

The island nations of the South Pacific raise general questions about "models" of industrial relations systems and provide material for comparative studies on the basis of traditional criteria such as trade union freedom and the right to strike. It is only natural that developing countries will give careful attention to the earlier experience of other

9 W Galenson Labour in Developing Economics (University of California Press, 1962) 6.

10 Quoted in Ross Industrial Relations and Economic Development (Macmillan, London, 1966) in the Introduction xxviii.

11 The Fijian oil-workers strike in 1959 can be seen as an early illustration of industrial action around which coalesced a number of social, political and racial issues. See (1984) 11 Journal of Pacific Studies 204. 
nations. The question for comparativists is whether the labour and industrial law which accompanied economic development in the older countries of the West are adequate for the situation of emerging Pacific Island nation states or the developing countries of Asia and Africa? A study of these developing countries provides an understanding of the importance of social, economic and political freedoms in countries which are in a hurry to emulate Western industrial development.

The experience of the island nations of the South Pacific is also valuable as a source of comparative study of the role of wage determination and of the place of collective bargaining. A viable system of collective bargaining takes many years to develop, as the history of any western country demonstrates, and the minimal requirements are equality of bargaining power, access to relevant information, and a neutral government. These ingredients are rarely found in the South Pacific. The absence of organised labour unions, especially in the agricultural sector, questions whether collective bargaining is a reality or only a facade and raises many important research questions including those relating to wage policy, economic development, wage arbitration criteria, workforce planning and the advantages and disadvantages of legislated, uniform minimum wages.

The unique character of the developing world's industrial relations systems has been emphasised by various writers in the past and different explanations have been put forward. The explanations can be broadly divided into two main groups. ${ }^{12}$ First, there is the popular cultural-based explanation. According to this explanation, such conditions as culture, tradition and custom are said to be primary influences on the industrial relations system. Moreover, it is often argued that these phenomena not only lead to a different industrial relations system from that of the industrialised west, but also differentiate the industrial relations system of one emerging country or region from another.

The second widely held reason for the difference between the industrial relations system of an emerging economy and that of the developed countries is based on the role of the state in the industrial relations system. It is claimed that whereas the industrial relations system in the developed countries of the west mainly evolved in a laissez-faire environment, where the state has played a relatively minor role, in most of the newly industrialising countries this is not the case. Most South Pacific countries have identified industrialisation as the most important step in their economic development after independence from colonial rule. The state in most cases has been entrusted with carrying out a massive industrialisation program to improve the economy. The state's intervention in the industrialisation process has inevitably led to its involvement in the industrial relations system in most South Pacific countries.

12 SA Siddique "Industrial Relations in a Third World Setting: A Possible Model" (1989) Journal of Industrial Relations especially 385-386. 
As Ross observed, thirty years ago, "in understanding the role of government in these countries, several facts must be kept in mind. Where independence has been acquired only recently the labour movement generally played an important part in the anti-colonial movement. Many government officials and national leaders are former trade union officials. Even in countries which have long been independent, the trade union movement is frequently an important source of political support for the government - a vital consideration in unstable countries. On the other hand, the stronger the unions become, the more insistently do they demand the higher wages and improved living standards which they are pledged to obtain. These demands confront the government with a set of dilemmas which have become familiar to students of economic development. Workers desire more consumer goods but savings are necessary for capital expansion. Unions press for wage increases but the government seeks to avoid inflation in order to conserve foreign exchange. A greater measure of economic equality has been promised, but this is not necessarily conducive to the highest rate of capital formation. Workers pour into the cities seeking employment, but job opportunities are limited if the most efficient productive methods are used.

The traditional concept of collective bargaining implies that the national wage structure will emerge from a multitude of uncoordinated bargaining decisions. In the developing nations of the South Pacific, however, the government's economic plans may call for another kind of wage structure. Likewise, the right to resort to economic strength is an important element in traditional collective bargaining theory, but most governments in the South Pacific believe that work stoppages cannot be tolerated because of the adverse effect on foreign investment, the danger to social cohesion and the interference with development plans". 13

The most obvious "development plan" in each of the independent island nations of the South Pacific is found in the Constitution and the process of building a Constitution once independence was gained has much to interest students of comparative constitutional law. These Constitutions are an important source of rights and obligations generally as well as for labour law and industrial relations in particular. An example is found in those Articles which enshrine fundamental human rights and freedoms. In the Constitution of the Independent State of Western Samoa the fundamental rights relevant to industrial relations and labour law include: freedom from forced labour (Article 8); the right of peaceful assembly and association (Article 13(1)(c)); freedom from discriminatory legislation (Article 15). A list of fundamental rights is also found in the Constitution of the Republic of Vanuatu. Those rights provide for forms of affirmative action by excluding from the principle of equal treatment before the law any provision which is made for "the special

13 Ross above n 10. 
benefit, welfare, protection or advancement of females, children and young persons, members of under-privileged groups or inhabitants of less developed areas." (Article 15(3)(b)).

Each of the South Pacific island nations has enacted legislation specifically directed at employment conditions. A typical example is the Industrial and Labour Ordinance of the Cook Islands. This Ordinance has nine Parts and covers: general administrative management; industrial unions; industrial agreements; settlement of industrial disputes; workers entitlement; health, welfare and safety; employment of women and children; accommodation for workers; offences and penalties. In addition the Cook Islands has enacted legislation covering compensation for work-related injuries; discrimination in employment; prohibitions on forced or compulsory labour; restrictions on the recruitment of persons for employment outside the Cook Islands; apprenticeship. The model is clearly that of the Anglo-Saxon legislative tradition of England, Australia and New Zealand. In addition, the traditional English common law regulating the creation of, the rights and obligations in, and the termination of an employment contract is widely applied in the South Pacific but it must be recognised that the European concept of employer and employee will be relevant only to that small proportion of the labour force which is urban and largely concentrated in the service sector and that it's application will require qualification and modification. ${ }^{14}$

\section{Conclusion}

The South Pacific Island states provide a model for post-colonial development which may be compared and contrasted with similar developments in East Africa, South East Asia, Latin America and the Caribbean. The South Pacific nations provide many illustrations of the tensions between a policy of "modernisation" and the desire to maintain traditional economic, social, cultural and political structures. Reconciling traditional cultural values with economic development is a challenge which faces all South Pacific nations. The many tensions involved in the process of critically evaluating laws inherited from a colonial past and incorporating these with traditional law into a post-independent legal system symbolised by a Constitution is a process of interest to students of law, sociology, politics and anthropology. The clearest illustration of the tensions, and of the difficulties in balancing these tensions, is found in a study of labour law. What the study of labour law in the South Pacific teaches is that law does not exist in a vacuum, that no one model of labour law and industrial relations will work in all countries, that no one system is necessarily superior or good, that the purpose of industrial regulation is to protect against exploitation and that the search for industrial justice is never ending. 


\section{Étude de droit comparé en droit du travail à la lumière de l'expérience des pays du Pacifique}

Les expériences diverses qu'ont connu les états insulaires de la région pacifique, alors qu'ils entraient de plein pied dans l'économie de marché, offrent de précieux instruments d'analyse pour la compréhension des conditions dans lesquels le droit du travail s'est progressivement formé. Il offre également une opportunité pour l'étude des effets induits par l'importation des normes légales et des institutions européennes. Les conséquences qui en découlent, varient d'un état à l'autre, corrélativement à l'étendue du processus de colonisation que chacun d'entre eux a pu connaître et de l'équilibre qu'il ont su instaurer entre la coutume et les contraintes inhérentes aux développement économique. Dès lors, un des domaine de prédilection du droit comparé est tout naturellement l'étude des conséquences de l'introduction des décisions judiciaires du pouvoir colonial au 19ième siècle, sur les traditions et les coutumes des pays insulaires du pacifique sud. A titre d'exemples, on ne citera que la notion d'employeur, et celle du versement d'une somme d'argent en contrepartie d'un travail, deux concepts totalement étrangers aux systèmes traditionnels basés sur une économie de subsistance.

L'étude de l'introduction de ces concepts intéresse tout autant les juristes que les sociologues et les anthropologues, et si besoin est, rappelle que les études comparatives sont par définition interdisciplinaires. l'introduction du capitalisme tout comme son évolution dans les pays en voie de développement, demeure un phénomène complexe et son appréhension passe aussi par l'étude du droit du travail.

Pareille problématique concerne aussi bien les pays d'Asie, d'Amérique Latine, des Caraibes, d'Afrique, que les pays de la zone Pacifique. Ces derniers offrent la particularité de fournir un exemple de développement post-colonial qui pourra etre comparé à ce qu'on connu d'autres pays dans une situation semblable. Seront ainsi mis en exergue, les tensions entre la politique dite de "modernisation" et le désir de maintenir des structures coutumières et traditionnelles. Tenter de concilier ces deux objectifs, souvent contradictoires est un des défis que doivent relever les pays insulaires de la zone Pacifique. L'introduction souvent forcée de règles héritées d'un passé colonial dans un contexte où la coutume est toujours fortement présente ne peut qu'induire des difficultés, le droit du travail en étant une parfaite illustration. L'étude de ce domaine du droit dans ce contexte particulier, permet de conclure, qu'en fait aucune tradition légale ne peut à elle seule offrir des solutions définitives qui lui assurerait une supériorité sur l'autre système. Le constat est en ce domaine plus nuancé, le compremis devant prévaloir. 